\title{
Authentic and Pragmatic Marketing Effects by Paradigm Shifts on Brand Authenticity to Produce Sustainable Value
}

\section{Zohreh Ali Esmaeli' ${ }^{\mathbb{D}}$ | Bahram Kheiri²* | Farzin Farahbod³}

'Islamic Azad University, Rasht Branch, Department of Marketing Management, Rasht, Iran ${ }^{2}$ Islamic Azad University, Tehran Markaz Branch, Department of Marketing Management, Tehran, Iran

IIslamic Azad University, Rasht Branch, Department of Marketing Management, Rasht, Iran

*Correspondence to: Bahram Kheiri, Islamic Azad University, Tehran Markaz Branch, Department of Marketing Management, Tehran, Iran.

E-mail: bahramkheiri@gmail.com

\begin{abstract}
This study aimed to investigate two marketing effects, namely, authentic and pragmatic, through paradigm shifts, as a solution to the epistemic crisis of brand authenticity. The research methods of this study were based on quantitative and descriptive surveys. The statistical population was 385 Iranian students at Islamic Azad Universities selected using stratified random sampling. The sample size was determined by Morgan's table. Data were collected and distributed by questionnaire. The structural equation modeling technique used the partial least squares approach for data analysis. The findings indicate that both authentic and pragmatic marketing are more effective on brand authenticity through paradigm shift. Sustainable value production was not separate from economic growth. Rather, it sustains growth, and this paradigm shift, while developing the knowledge economy, affects the quality of a university-produced product. This makes it a prominent and authentic cultural institution, because brand originality has content in social interaction.
\end{abstract}

Keywords: authentic brand, authentic marketing, paradigm shift, pragmatic marketing.

Article info: Received 29 September 2019| revised 19 November 2019| accepted 30 November 2019

Recommended citation: Esmaeli, Z. A., Kheiri, B., \& Farahbod, F. (2019). Authentic and Pragmatic Marketing Effects by Paradigm Shifts on Brand Authenticity to Produce Sustainable Value. Indonesian Journal of Sustainability Accounting and Management, 3(2), 227-238. https://doi.org/10.28992/ijsam.v3i2.112.

\section{INTRODUCTION}

Kotler \& Zaltman (1997) considered the transaction as a "social exchange" process in a paper that describes the concept of marketing as a social exchange process. Accordingly, the purely economic viewpoint of marketing is a mistake of proximity and it hinders the development of marketing science (Haghighi et al., 2012). Kotler et al. (2019) calls marketing as the era of value creation, and marketing managers, instead of treating people as consumers, regard them as people with the brain, heart, and soul, marketing is not a process that only marketers follow in their relationship with the consumer (Kotler et al., 2019). Consumers also use marketing in their daily communication. Third-age marketing sees customer as a human being, the human 
being has four basic elements, a body, a mind that has the ability to think and analyze independently, the heart that can feel the emotions and the spirit or philosophical center of the body, hence he considers authenticity or credibility as the most effective element of the new age in creating sustainable development (Kotler et al., 2019).

In a world full of complexity, customers are looking for companies that meet their deep needs for social, economic, and environmental justice in mission, vision and values. Not only do they seek to meet their functional and emotional needs in the products and services they choose, but also meeting spiritual needs is important for them. Third-age marketing moves the concept of marketing to ideals, values, and spiritualties, and believes that consumers are perfect people and their needs and expectations should not be ignored. Therefore, third-age marketing combines "emotional" marketing with "spiritual" marketing (Kotler et al., 2019).

Bagozzi (2011) explains the evolution of marketing concepts in two aspects of philosophy of science and the universe. Cultural marketing is the second most important marketing element of the third age. Third-age marketing is an approach that does not overlook the concerns and interests of global citizens. Marketers of the third age must understand the problems of the community that are related to their business (Kotler et al., 2019). The concept of community interest is considered in the new definition of the 2008 American Marketing Association. According to this definition, marketing is a set of activities and processes for establishing communication, supply and exchange of proposals that are valued for consumers, clients, partners and society (Kotler et al., 2019).

How can companies create value in their business models? As a response to this fundamental question, Richard Barrett believes companies can look at levels of spirituality in their business models, like humans. He found that human level of spiritual motivation can be considered in the mission, vision and value of companies (Barrett-Lennard, 1998). Given today's customers' need for genuine values and the inefficiencies of existing paradigms to gain customer trust and producing sustainable value, the inefficiency of the paradigm in the Iranian higher education system in producing the original brand of this study examines two originality marketing, first authentic marketing in order to construct and deepen concepts through dialectics in language based on social platforms and the latter with pragmatic marketing in order to achieve authenticity in practice through the experience of theoretical reason in social or dialectical practice, which is examined by the mediating variable of paradigm shifts (from object-based ontology to phenomenology of existence) to their effect on the original brand.

Various meanings and types of authenticity (e.g. as attribute of objects, an existential experience of 'true self') are in addition imposed by different research traditions (Reisinger \& Steiner, 2006). It is thus no surprise that Reisinger \& Steiner (2006) conclude that the different views on (object) authenticity are conflicting and irreconcilable. Kolar \& Zabkar (2010), focused both types of authenticity in Truism industry. They acknowledge the distinction between object-based authenticity and existential authenticity, as they pertain to different entities (i.e. object/offerings and tourist existence/self) that should be considered separately, but they did not show according to contemporary field conditions. which paradigm is necessary for engaging customers and solving epistemic crisis to produce sustainable value This study, with the definition of authentic marketing, seeks to remove the corner of this theoretical vacuum of value interactions and authentic it in the practice. Kotler et al. (2019) emphasizes the importance of creating sustainable credit values and proposes the zi model for producing sustainable value based on three principles of nature, integrity and distinction (validity and authenticity). But what is so remarkable in existing studies is the lack of field research to build a model and reliance on scholars to examine existing literature. Therefore, the dimensions of authentic value as a framework for achieving the goal of sustainable growth in today's world, and its predecessors and 
consequences, and its interactions and oppositions with the authentically of the operation, have deficiencies that researchers themselves find in this field. Regarding the persistence of authentic and value-driven encounter in society and its biased application in favor of a particular opinion, the need to redefine the concept and subject matter as well as methods and tools according to contemporary field conditions is an inevitable necessity.

\section{METHODS}

The present study is a quantitative research in terms of approach, in which the researcher collects data with predetermined tools that result in the statistical data, and is of a descriptive type. In descriptive research, the researcher seeks out how and what he wants to know about the phenomenon or variable. In other words, this study examines the status quo and systematically describes its current status, explores its features and traits, and examines the relationship between variables if necessary. Since the purpose of this study is to describe the presentation of a native model for authentic marketing and pragmatic marketing and their interaction and contrast, this research is considered as a descriptive study.

Surveying is a way to obtain data about the views, beliefs, opinions, behaviors or characteristics of a group of members of a statistical community through research. Data is collected by asking people who are regularly selected and grouped into sample groups. Therefore, this research is a survey type. In the quantitative section, the descriptive-survey research method was used to evaluate the described phenomenon. The statistical community can be defined as: all elements and individuals that share one or more attributes on a given geographic scale (global, regional, local, or spatial). The statistical population of this study is students of selected Azad Universities (Anzali, Tehran Center, Tonekabon). Due to the extent of selected universities, stratified random sampling method was used. In stratified sampling, the units of the study population are grouped into categories that are more homogeneously variable in order to minimize variations within groups. Then, some samples are randomly selected from each class. Thus, the selected free universities were divided into three classes, Anzali, Tehran Center, Tonekabon, assuming that the students of the free universities were homogeneous. Then, at each free university, student consensus centers such as corridors, campus and classrooms were selected and the researcher randomly referred to student consensus centers and, after giving a brief explanation of the research topic, were asked to fill out a questionnaire if they were university students. And the sample size calculated 385 people based on Morgan's Table. Questionnaire was used for data collection. The questionnaire contains Several questions about the variables measured by the study population. These questions are constructed using specific techniques as well as scales so that the desired information can be gathered from the study population or sample. The questions in this section are also designed based on a five (5) point Likert range.

\section{RESULTS AND DISCUSSION}

Descriptive statistics specifies the general characteristics of the population under study and its general characteristics for other researchers. In addition, this knowledge can be used to generalize the results to other communities, or to design future research questions for other communities. The descriptive statistics of the research are described in Tables 1 and 2.

Are the questions for measuring variables properly selected? Confirmatory Factor Analysis (CFA) is used for this purpose, such that the factor loading of each marker with its construct has a significant $t$-value at $5 \%$ 
error level, that is to be outside the range of -1.96 and -1.96 , and also the factor loading of each marker with its construct is greater than 0.5 , this marker is then accurate enough to measure that structure or latent traits. For this purpose, confirmatory factor analysis was performed on questionnaire items as described in Tables 3 and 4. As you can be observed, the goodness of fit index for all the hypotheses is in the strong range (Tables 5 and 6). That is, the internal model is robust enough to test hypotheses and the test results can be statistically reliable.

Based on the internal model obtained from the research hypotheses test, the validation or rejection of the research hypotheses will be examined. To confirm or reject the hypotheses, a significant coefficient ( $t-$ statistic) is used, if the $t$-statistic is greater than -1.96 or less than -1.96 (at $5 \%$ error level), the hypotheses is confirmed and a significant relationship is obtained between the two hidden variables. The results of the hypotheses analysis are presented in Tables 7 and 8.

The path coefficient of the authentic marketing effect on the paradigm shift is 0.15 and has a t-value of 3.40. The $t$-value for this parameter is calculated more than 2.58. Therefore, the null hypotheses is rejected with $99 \%$ confidence. That is, there is a significant relationship between the authentic marketing and the paradigm shift and the authentic marketing is effective on the paradigm shift. Therefore, this research hypotheses is accepted.

The significant impact of authentic marketing on paradigm shifts is consistent with the results of Kotler et al. (2019); Moulard et al. (2015). The relationship between authenticity and spirit or philosophical center of human and he phenomenal of originality are consistent with the existence of the phenomenon, showing that authentic marketing of university is effective on the community through changing paradigm shift and there is a need for original marketing with a new ontology to offer genuine value, create new concepts and enhance the quality of community spirituality.

The path coefficient of the effect of pragmatic marketing on the paradigm shift is 0.63 and has a t-value of 15.35. The $t$-value for this parameter is calculated more than 2.58. Therefore, the null hypotheses is rejected with $99 \%$ confidence. That is, there is a significant relationship between pragmatic marketing and paradigm shift and pragmatic marketing is effective on the paradigm shift. Therefore, this research hypotheses is accepted.

Table 1 Frequency Distribution by Age Category

\begin{tabular}{lccc}
\hline & Age range & Frequency & Percentage \\
\hline $18-28$ years & & 337 & 54.5 \\
$28-38$ years & & 159 & 25.7 \\
$38-48$ years & & 102 & 16.5 \\
48 years and more & & 20 & 3.2 \\
\hline & Total & 618 & 100 \\
\hline
\end{tabular}

Table 2 Frequency Distribution by Education Level

\begin{tabular}{lccc}
\hline & Education & Frequency & Percentage \\
\hline Bachelor's degree & & 197 & 31.9 \\
Master's degree & & 351 & 56.8 \\
Doctorate & Total & 70 & 11.3 \\
\hline
\end{tabular}


Table 3 Factor Loading and Significance of Questions (First-Order Analysis)

\begin{tabular}{|c|c|c|c|}
\hline Variable & Question & Factor Loading & Significance \\
\hline \multirow[t]{11}{*}{ Authentic marketing } & $\mathrm{AA} 1$ & 0.5 & 13.49 \\
\hline & $\mathrm{A} A 2$ & 0.54 & 14.92 \\
\hline & $A_{3} 3$ & 0.62 & 17.46 \\
\hline & $A B 1$ & 0.76 & 39.49 \\
\hline & $A B 3$ & 0.51 & 11.94 \\
\hline & $\mathrm{AC} 1$ & 0.80 & 45.69 \\
\hline & $\mathrm{AC2}$ & 0.86 & 66.21 \\
\hline & $\mathrm{AC}_{3}$ & 0.85 & 66.48 \\
\hline & AD1 & 0.88 & 93.13 \\
\hline & $A D 2$ & 0.76 & 37.11 \\
\hline & $A_{3} 3$ & 0.73 & 33.22 \\
\hline \multirow[t]{11}{*}{ Pragmatic marketing } & BA1 & 0.66 & 25.38 \\
\hline & BA2 & 0.78 & 45.24 \\
\hline & BB1 & 0.83 & 56.39 \\
\hline & BB2 & 0.83 & 53.59 \\
\hline & BB3 & 0.84 & 56.25 \\
\hline & $\mathrm{BC} 1$ & 0.87 & 40.21 \\
\hline & $B C 2$ & 0.78 & 39.47 \\
\hline & $\mathrm{BC}_{3}$ & 0.61 & 18.39 \\
\hline & BD1 & 0.83 & 56.16 \\
\hline & BD2 & 0.82 & 49.15 \\
\hline & $\mathrm{BD}_{3}$ & 0.85 & 59.72 \\
\hline \multirow[t]{11}{*}{ Paradigm shift } & CA1 & 0.65 & 22.56 \\
\hline & $\mathrm{CA} 2$ & 0.58 & 16.89 \\
\hline & CB1 & 0.74 & 31.63 \\
\hline & CB2 & 0.72 & 28.76 \\
\hline & $\mathrm{CB}_{3}$ & 0.72 & 30.01 \\
\hline & $\mathrm{CC} 1$ & 0.79 & 51.00 \\
\hline & $\mathrm{CC} 2$ & 0.75 & 38.53 \\
\hline & $\mathrm{CC}_{3}$ & 0.76 & 48.10 \\
\hline & CD1 & 0.79 & 47.48 \\
\hline & $\mathrm{CD} 2$ & 0.83 & 67.33 \\
\hline & $\mathrm{CD}_{3}$ & 0.76 & 34.55 \\
\hline \multirow[t]{3}{*}{ Authentic brand } & D1 & 0.89 & 111.84 \\
\hline & D2 & 0.90 & 96.34 \\
\hline & D3 & 0.74 & 28.13 \\
\hline
\end{tabular}

The significant effect of pragmatic marketing on the paradigm shifts is consistent with the research results of Bell \& Brown (1990) who incorporated the practical attitude of pragmatic marketing to confront the consequences of their beliefs, the problem solving process in the social practice and the reinforcement of science and practice in an interactive approach between university and industry and showed that universities will be able to establish a sustainable interaction between philosophy and practice through a paradigm shift in pragmatic marketing, leading to sustainable resource growth.

The path coefficient of the effect of paradigm shift on the original brand is 0.77 and has a $t$-value of 46.92. The $t$-value for this parameter is calculated more than 2.56. Therefore, the null hypotheses is rejected with $99 \%$ confidence. That is, there is a significant relationship between the paradigm shift and the original brand and the paradigm shift does not affect the original brand. Therefore, this research hypotheses is accepted. 
Significance of paradigm shift's effect on original brand is consistent with research results of Cowan (2012), on the need to change paradigm shift when relationship regulation comes with epistemic crisis and it shows that changing the paradigm shift of the selected universities can add to their brand authenticity and contribute to their sustainable value creation.

Table 4 Factor Loading and Significance of Questions (Second-Order Analysis)

\begin{tabular}{|c|c|c|c|}
\hline Variable & Question & Factor Loading & Significance \\
\hline \multirow{3}{*}{ Authentic marketing paradigm } & $\mathrm{AA} 1$ & 0.82 & 39.88 \\
\hline & $\mathrm{A} A 2$ & 0.84 & 49.95 \\
\hline & $\mathrm{AA} 3$ & 0.84 & 40.51 \\
\hline \multirow[t]{3}{*}{ Making social platforms } & $A B 1$ & 0.81 & 40.22 \\
\hline & $A B_{2}$ & 0.73 & 19.68 \\
\hline & $A B_{3}$ & 0.81 & 37.29 \\
\hline \multirow[t]{3}{*}{ Authentic marketing mix } & $A C 1$ & 0.88 & 80.91 \\
\hline & $\mathrm{AC2}$ & 0.93 & 139.68 \\
\hline & $\mathrm{AC}_{3}$ & 0.87 & 50.75 \\
\hline \multirow[t]{3}{*}{ Authentic values } & AD1 & 0.91 & 113.12 \\
\hline & $A D 2$ & 0.85 & 49.09 \\
\hline & $A_{3}$ & 0.83 & 42.49 \\
\hline \multirow[t]{2}{*}{ Pragmatism } & $\mathrm{BA} 1$ & 0.85 & 44.82 \\
\hline & BA2 & 0.92 & 131.40 \\
\hline \multirow[t]{3}{*}{ Problem-oriented } & BB1 & 0.93 & 125.46 \\
\hline & $\mathrm{BB} 2$ & 0.91 & 84.94 \\
\hline & BB3 & 0.92 & 104.45 \\
\hline \multirow[t]{3}{*}{ Evolutionary product } & $\mathrm{BC} 1$ & 0.89 & 78.74 \\
\hline & $\mathrm{BC} 2$ & 0.89 & 68.85 \\
\hline & $\mathrm{BC}_{3}$ & 0.76 & 31.59 \\
\hline \multirow[t]{3}{*}{ The process of strategic formulation of pragmatic marketing } & BD1 & 0.88 & 78.98 \\
\hline & $\mathrm{BD} 2$ & 0.92 & 102.04 \\
\hline & $\mathrm{BD}_{3}$ & 0.93 & 108.89 \\
\hline \multirow[t]{2}{*}{ Epistemological change } & CA1 & 0.91 & 89.58 \\
\hline & $\mathrm{CA} 2$ & 0.88 & 56.23 \\
\hline \multirow[t]{3}{*}{ Ontological change } & CB1 & 0.88 & 58.40 \\
\hline & $\mathrm{CB}_{2}$ & 0.93 & 100.97 \\
\hline & $\mathrm{CB}_{3}$ & 0.94 & 104.96 \\
\hline \multirow[t]{3}{*}{ Consumer growth } & $\mathrm{CC} 1$ & 0.86 & 76.88 \\
\hline & $C C_{2}$ & 0.84 & 51.63 \\
\hline & $\mathrm{CC}_{3}$ & 0.90 & 97.78 \\
\hline \multirow[t]{3}{*}{ Out-of-structure changes } & CD1 & 0.83 & 49.37 \\
\hline & $\mathrm{CD} 2$ & 0.90 & 118.03 \\
\hline & $\mathrm{CD}_{3}$ & 0.85 & 59.01 \\
\hline
\end{tabular}

Table 5 Calculation of Internal Model Fitting (First-Order Analysis)

\begin{tabular}{lcc}
\hline \multicolumn{1}{c}{ Variable } & Communality & $\mathrm{R}^{2}$ \\
\hline Authentic marketing & 0.52 & 0.00 \\
Pragmatic marketing & 0.62 & 0.00 \\
Paradigm shift & 0.55 & 0.55 \\
Original brand & 0.72 & 0.59 \\
\hline Goodness of fit index & & 0.59 \\
\hline
\end{tabular}


Table 6 Calculating the Fit of the Internal Model of Second-Order Hypotheses

\begin{tabular}{|c|c|c|}
\hline Variable & Communality & $\mathrm{R}^{2}$ \\
\hline Authentic marketing variable & 0.69 & 0.00 \\
\hline Building social platforms & 0.62 & 0.00 \\
\hline Authentic marketing mix & 0.80 & 0.00 \\
\hline Authentic values & 0.75 & 0.00 \\
\hline Pragmatism & 0.79 & 0.00 \\
\hline Problem-oriented & 0.85 & 0.00 \\
\hline Evolutionary product & 0.72 & 0.00 \\
\hline The process of strategic formulation of pragmatic marketing & 0.83 & 0.00 \\
\hline Epistemological change & 0.81 & 0.17 \\
\hline Ontological change & 0.84 & 0.53 \\
\hline Consumer growth & 0.75 & 0.43 \\
\hline Out-of-structure changes & 0.74 & 0.50 \\
\hline Brand authentic & 0.72 & 0.66 \\
\hline Goodness of fit index & 0.59 & \\
\hline
\end{tabular}

Table 7 Results of Partial Least Squares Analysis for First-Order Research Hypotheses

\begin{tabular}{|c|c|c|c|c|}
\hline $\begin{array}{l}\text { Number of } \\
\text { Hypotheses }\end{array}$ & Hypotheses & $\begin{array}{c}\text { Path } \\
\text { Coefficients }\end{array}$ & $\begin{array}{l}\text { Significance } \\
\text { Value }\end{array}$ & $\begin{array}{c}\text { Test } \\
\text { Result }\end{array}$ \\
\hline $\mathrm{H} 1$ & $\begin{array}{l}\text { Authentic marketing has a significant effect on the } \\
\text { paradigm shift }\end{array}$ & 0.15 & 3.40 & Confirmed \\
\hline $\mathrm{H}_{2}$ & $\begin{array}{l}\text { Pragmatic marketing has a significant effect on the } \\
\text { paradigm shift }\end{array}$ & 0.63 & 15.35 & Confirmed \\
\hline $\mathrm{H}_{3}$ & $\begin{array}{l}\text { The paradigm shift has a significant effect on the } \\
\text { original brand }\end{array}$ & 0.77 & 46.92 & Confirmed \\
\hline $\mathrm{H}_{4}$ & $\begin{array}{l}\text { Original marketing has a significant impact on the } \\
\text { original brand with the mediating role of paradigm } \\
\text { shift }\end{array}$ & \multicolumn{2}{|c|}{0.11} & Confirmed \\
\hline $\mathrm{H}_{5}$ & $\begin{array}{l}\text { Pragmatic marketing has a significant impact on the } \\
\text { original brand with the mediating role of paradigm } \\
\text { shift }\end{array}$ & \multicolumn{2}{|c|}{0.48} & Confirmed \\
\hline
\end{tabular}

Given the confirmation of the first path, i.e. the effect of original marketing on the paradigm shift, as well as the confirmation of the second path, i.e. the effect of the paradigm shift on the original brand, all paths related to this hypotheses have been confirmed; therefore, the null hypotheses is rejected with $95 \%$ confidence. That is, authentic marketing has a significant impact on the original brand with the mediating role of paradigm shift. Therefore, the paradigm shift variable plays a mediating role here. Moreover, the effect of original marketing with the mediating role of paradigm shift on the original brand is 0.11 .

The significant impact of authentic marketing by shift paradigm on original brand is consistent with the research results of Quinton (2013); Kim et al. (2014) in relation to the phenomenological effect of philosophical hermeneutics on deep understanding of phenomena and their asymmetry in existence, the creation of transcendental concepts based on the lived experience of each person, through hermeneutic understanding of concepts in dialectics based on language. On this basis, the selected universities can change their ontology to the phenomenology of existence and dialectics in the concepts that are effective in shaping their original brand content. 
Table 8 Partial Least Squares Analysis Results for Second-Order Research Hypotheses

\begin{tabular}{|c|c|c|c|c|}
\hline $\begin{array}{l}\text { Number of } \\
\text { Hypotheses }\end{array}$ & Hypotheses & $\begin{array}{c}\text { Path } \\
\text { Coefficient }\end{array}$ & $\begin{array}{l}\text { Significance } \\
\text { Value }\end{array}$ & $\begin{array}{l}\text { Test } \\
\text { Result }\end{array}$ \\
\hline $\mathrm{H} 6$ & $\begin{array}{l}\text { The authentic marketing paradigm has an impact on } \\
\text { the ontological change }\end{array}$ & -0.12 & 2.48 & Accepted \\
\hline $\mathrm{H} 7$ & $\begin{array}{l}\text { Building social platforms has an impact on ontological } \\
\text { change }\end{array}$ & 0.10 & 1.76 & Rejected \\
\hline $\mathrm{H} 8$ & $\begin{array}{l}\text { The original marketing mix has an impact on the } \\
\text { ontological change }\end{array}$ & 0.02 & 0.27 & Rejected \\
\hline $\mathrm{H} 9$ & $\begin{array}{l}\text { Authentic values have an effect on epistemological } \\
\text { change }\end{array}$ & 0.06 & 0.80 & Rejected \\
\hline $\mathrm{H} 10$ & $\begin{array}{l}\text { Pragmatism has an effect on the epistemological } \\
\text { change }\end{array}$ & -0.13 & 2.07 & Accepted \\
\hline $\mathrm{H} 11$ & $\begin{array}{l}\text { Problem-centeredness has on effect on } \\
\text { epistemological change }\end{array}$ & 0.25 & 3.73 & Accepted \\
\hline $\mathrm{H} 12$ & $\begin{array}{l}\text { The evolutionary product has an impact on } \\
\text { epistemological change }\end{array}$ & 0.16 & 2.43 & Accepted \\
\hline $\mathrm{H} 13$ & $\begin{array}{l}\text { The process of strategic formulation of pragmatic } \\
\text { marketing has an impact on epistemological change }\end{array}$ & 0.06 & 0.68 & Rejected \\
\hline $\mathrm{H} 14$ & $\begin{array}{l}\text { The original marketing paradigm has an impact on } \\
\text { ontology change }\end{array}$ & 0.10 & 2.48 & Accepted \\
\hline $\mathrm{H} 15$ & $\begin{array}{l}\text { Building social platforms has an impact on ontological } \\
\text { change }\end{array}$ & 0.06 & 1.72 & Rejected \\
\hline $\mathrm{H} 16$ & $\begin{array}{l}\text { The authentic marketing mix has an impact on } \\
\text { ontological change }\end{array}$ & 0.01 & 0.14 & Rejected \\
\hline H17 & $\begin{array}{l}\text { Authentic values have an impact on ontological } \\
\text { change }\end{array}$ & 0.02 & 0.36 & Rejected \\
\hline $\mathrm{H} 18$ & Pragmatism has an effect on ontological change & -0.07 & 1.52 & Rejected \\
\hline $\mathrm{H} 19$ & $\begin{array}{l}\text { Problem-centeredness has an effect on ontological } \\
\text { change }\end{array}$ & 0.13 & 2.37 & Accepted \\
\hline $\mathrm{H}_{2} \mathrm{O}$ & $\begin{array}{l}\text { The evolutionary product has an effect on ontological } \\
\text { change }\end{array}$ & 0.19 & 3.40 & Accepted \\
\hline $\mathrm{H} 21$ & $\begin{array}{l}\text { The process of strategic formulation of pragmatic } \\
\text { marketing has an effect on ontological change }\end{array}$ & 0.41 & 5.77 & Accepted \\
\hline $\mathrm{H} 22$ & $\begin{array}{l}\text { The original marketing paradigm has an impact on } \\
\text { consumer growth }\end{array}$ & -0.14 & 3.51 & Accepted \\
\hline $\mathrm{H}_{23}$ & $\begin{array}{l}\text { Building social platforms has an impact on consumer } \\
\text { growth }\end{array}$ & 0.07 & 1.61 & Rejected \\
\hline $\mathrm{H} 24$ & $\begin{array}{l}\text { Authentic marketing mix has an impact on consumer } \\
\text { growth }\end{array}$ & 0.18 & 2.87 & Accepted \\
\hline $\mathrm{H} 25$ & Authentic values have an effect on consumer growth & -0.03 & 0.59 & Rejected \\
\hline $\mathrm{H}_{2} 6$ & Pragmatism has an impact on consumer growth & 0.16 & 3.22 & Accepted \\
\hline $\mathrm{H} 27$ & $\begin{array}{l}\text { Problem-centeredness has an impact on consumer } \\
\text { growth }\end{array}$ & 0.12 & 2.19 & Accepted \\
\hline $\mathrm{H} 28$ & $\begin{array}{l}\text { The evolutionary product has an impact on consumer } \\
\text { growth }\end{array}$ & 0.08 & 1.76 & Rejected \\
\hline $\mathrm{H} 29$ & $\begin{array}{l}\text { The process of strategic formulation of pragmatic } \\
\text { marketing has an impact on consumer growth }\end{array}$ & 0.27 & 4.22 & Accepted \\
\hline $\mathrm{H}_{3} \mathrm{O}$ & $\begin{array}{l}\text { The authentic marketing paradigm has an effect on } \\
\text { out-of-structure changes }\end{array}$ & -0.10 & 2.75 & Accepted \\
\hline $\mathrm{H}_{31}$ & $\begin{array}{l}\text { Building social platforms has an effect on out-of- } \\
\text { structure changes }\end{array}$ & 0.04 & 0.81 & Rejected \\
\hline $\mathrm{H} 32$ & $\begin{array}{l}\text { Authentic marketing mix has an effect on out-of- } \\
\text { structure changes }\end{array}$ & 0.05 & 0.89 & Rejected \\
\hline
\end{tabular}




\begin{tabular}{|c|c|c|c|c|}
\hline $\begin{array}{l}\text { Number of } \\
\text { Hypotheses }\end{array}$ & Hypotheses & $\begin{array}{c}\text { Path } \\
\text { Coefficient }\end{array}$ & $\begin{array}{l}\text { Significance } \\
\text { Value }\end{array}$ & $\begin{array}{l}\text { Test } \\
\text { Result }\end{array}$ \\
\hline $\mathrm{H} 33$ & $\begin{array}{l}\text { Authentic values have an effect on out-of-structure } \\
\text { changes }\end{array}$ & 0.13 & 2.15 & Accepted \\
\hline $\mathrm{H} 34$ & $\begin{array}{l}\text { Pragmatism has an effect on out-of-structure } \\
\text { changes }\end{array}$ & 0.05 & 1.00 & Rejected \\
\hline $\mathrm{H} 35$ & $\begin{array}{l}\text { Problem-centeredness has an effect on out-of- } \\
\text { structure changes }\end{array}$ & 0.14 & 2.56 & Accepted \\
\hline $\mathrm{H} 36$ & $\begin{array}{l}\text { Evolutionary product has an effect on out-of- } \\
\text { structure changes }\end{array}$ & 0.09 & 1.98 & Accepted \\
\hline $\mathrm{H} 37$ & $\begin{array}{l}\text { The process of strategic formulation of pragmatic } \\
\text { marketing has an effect on out-of-structure changes }\end{array}$ & 0.38 & 6.14 & Accepted \\
\hline $\mathrm{H}_{3} 8$ & $\begin{array}{l}\text { Epistemological change gas an effect on the original } \\
\text { brand }\end{array}$ & -0.02 & 0.86 & Rejected \\
\hline H39 & Ontology change has an effect on the original brand & -0.02 & 0.56 & Rejected \\
\hline $\mathrm{H} 4 \mathrm{O}$ & Consumer growth has an effect on the original brand & 0.39 & 9.47 & Accepted \\
\hline $\mathrm{H} 41$ & $\begin{array}{l}\text { Out-of-structure changes have an effect on the } \\
\text { original brand }\end{array}$ & 0.49 & 11.58 & Accepted \\
\hline
\end{tabular}

Given the confirmation of the first path, i.e. the impact of pragmatic marketing on the paradigm shift, and the second path confirmation, i.e. the effect of the paradigm shift on the original brand, all paths related to this hypotheses have been confirmed, so the null hypotheses is rejected with $95 \%$ confidence. That is, pragmatic marketing has a significant impact on the original brand with the mediating role of paradigm shift. Therefore, the paradigm shift variable plays a mediating role here. Therefore, the effect of pragmatic marketing with the mediating role of paradigm shift on the original brand is 0.48 . Significance of pragmatic marketing through paradigm shift of the original brand is consistent with the research results of Japutra et al. (2018); White et al. (2019), which considers the dialectical and progressive view as a social, ever-changing and evolving phenomenon. They have always been negative and replaced by positive, progressive and revolutionary elements. Universities can recognize the negative practical consequences of the theories and target them to increase the utility of society by shifting the paradigm shift to the phenomenology of existence and the dialectics of science and practice between academia and industry.

The significance of hypotheses 6, 14, 22, 24, 35, 30 is consistent with Kotler et al. (2019) research that the output of authenticity must be phenomenologically real and internally valid. Consumers no longer want to consume alone and are themselves the creators of new lifestyles, and also with research findings of Kotler et al. (2019). The creation of their consumers has entered the process of value creation to solve social, cultural and economic problems and are no longer passive and have become innovators seeking the spiritual and cultural world and also with research results of Kotler et al. (2019) as clergy and spirituality as valuable aspects of immaterial life and sustainable realities in creative societies. Accordingly, it is suggested that to validate their brand internally, selected universities can use students' presence and creativity to produce new styles and innovations in solving social, economic, and cultural issues by shifting the paradigm of phenomenology to make their role as a spiritual and cultural institution in society more desirable.

Disapproval of hypotheses 7, 8, 9, 15, 16, 17, 23, 25, 31, 32, 38, 39, with Cenamor et al. (2019) research that platform is a business. Platforms create value through interaction and new social arrangements that develop concepts over time. It also does not consistent with the research conducted by Rose \& Orr (2007); Han et al. (2016); Luna-Cortés (2017); Bairrada et al. (2018) that customers pay money for symbolic meanings in the postmodern marketing, indicating that in the study community, building social platforms and making meaningful products does not necessarily have a significant relationship with paradigm shift. In addition, there 
is no significant relationship between ontology and epistemology on brand originality in this society and further research is needed in these cases.

Significance of hypotheses 10, 11, 12, 19, 20, 21, 26, 27, 29, 35, 36, 37, is consistent with research results obtained by Bull \& Ridley-Duff (2019) that pragmatic marketing seeks to produce an evolutionary product based on social criticism. According to the research results obtained by White et al. (2019), pragmatic marketing should address the problems of the community and improve the current state of society. Similarly, selected universities can produce evolutionary products to respond to economic, social, cultural problems by strategically planning pragmatic marketing.

Rejecting the hypotheses 13, 19, 28, 34 does not consistent with the results of Majeed (2019). Pragmatism means theoretical reasoning and suggests that pragmatism does not necessarily have ontological change in the studied community and social change as well as evolutionary product has no significant relationship with consumer growth, in which case more research is needed.

The significance of hypotheses 40, 41 with research results of Abdollahian \& Alsharabati (2003), regarding the increase and interference of channels of comprehensiveness in the new technology era that impose conditions of out-of-structure changes on societies. Society faces multiple valuations that disputes credits such as authenticity and disbelief. It also consistent with research results obtained by Kotler et al. (2019), in the current age when word of mouth has become a new medium and consumers are more trusted by strangers in their community than corporations. Businessmen without authenticity will have no chance of survival. On this basis, it is recommended that selected universities plan to increase their authenticity based on continuous and sustained interaction with the student in order to gain more existence due to consumer growth in value sharing and increasing conflict of value socialization channels.

\section{CONCLUSION}

Since the customer trust in brands has diminished and the validity of the value presented by the brand has been decreased, achieving brand authenticity is essential to producing sustainable value. And given that in the new technology era, vertical communication has transformed marketers and customers into horizontal communications, and that their creators and marketers have been competing with them, engaging more customers in the value chain of the company and adding brand authenticity led the organization to produce sustainable value.

Marketing with phenomenological ontology is a kind of postmodern marketing and its methodology is a combination of structured and semi-structured methods. On the other hand, by reducing the quality, increasing the orientation of the universities and the degree of community orientation that results in the decrease of the level of culture and the growth of the society, the purpose of this research is to show that in the age of globalization, new generation technology and communication rationality, universities To achieve brand authenticity, what can produce sustainable value requires paradigm shifts in ontology and epistemology in their view of students, and to be phenomenological rather than object and commodity, and seek through sustained interaction With them to gain their inner creativity and experience so that they can generate value and culture in the community have a sustainable growth. Elements of paradigm shift, namely consumer growth and out-of-structure changes, affect brand authenticity, so universities can create the atmosphere of emergence and emergence of students' talent and their ongoing engagement with themselves, with industry, society, culture. Until they can Manage the out-of-structure changes and guide it towards social, cultural and spiritual alternatives. 
The goal of changing ontological view in university is to avoid considering the customer as an instrument, getting internal experience, creativity and sustained customer interaction are key to sustainable knowledge development. Sustainable value production is not separate from economic growth, but it sustains growth, and this paradigm shift, while developing the knowledge economy, affects the quality of university-produced product, making it a prominent and authentic cultural institution, because brand originality has content in social interaction.

\section{ORCID}

Zohreh Ali Esmaeli (iD https://orcid.org/0000-0001-77444-7749

\section{REFERENCES}

Abdollahian, M., \& Alsharabati, C. (2003). Modeling the Strategic Effects of Risk and Perceptions in Linkage Politics. Rationality and Society, 15(1), 113-135. https://doi.org/10.1177/1043463103015001074

Bagozzi, R. P. (2011). The Evolution of Marketing Thought: From Economic to Social Exchange and Beyond. In P. Maclaran, M. Saren, B. Stern, \& M. Tadajewski (Eds.), The SAGE Handbook of Marketing Theory (pp. 244-265). https://doi.org/10.4135/9781446222454.n14

Bairrada, C. M., Coelho, F., \& Coelho, A. (2018). Antecedents and Outcomes of Brand Love: Utilitarian and Symbolic Brand Qualities. European Journal of Marketing, 52(3/4), 656-682. https://doi.org/10.1108/EJM02-2016-0081

Barrett-Lennard, G. T. (1998). Carl Rogers' Helping System: Journey and Substance. https://doi.org/10.4135/9781446217894

Bell, J., \& Brown, S. (1990). Pragmatic Perspectives in International Marketing Education. Journal of Management Development, 9(1), 39-50. https://doi.org/10.1108/02621719010135291

Bull, M., \& Ridley-Duff, R. (2019). Towards an Appreciation of Ethics in Social Enterprise Business Models. Journal of Business Ethics, 159(3), 619-634. https://doi.org/10.1007/s10551-018-3794-5

Cenamor, J., Parida, V., \& Wincent, J. (2019). How Entrepreneurial SMEs Compete through Digital Platforms: The Roles of Digital Platform Capability, Network Capability and Ambidexterity. Journal of Business Research, 100, 196-206. https://doi.org/10.1016/j.jbusres.2019.03.035

Cowan, K. (2012). Changing the Face of Retail: Where Fashion Meets Technology. Retrieved from Guardian News and Media Limited website: https://www.theguardian.com/media-network/media-networkblog/2012/may/16/retail-technology-decoded-fashion-2012

Haghighi, M., Dorosti, A., Rahnama, A., \& Hoseinpour, A. (2012). Evaluation of Factors Affecting Customer Loyalty in the Restaurant Industry. African Journal of Business Management, 6(14), 5039-5046. https://doi.org/10.5897/AJBM11.2765

Han, S. H., Nguyen, B., \& Simkin, L. (2016). The Dynamic Models of Consumers' Symbolic Needs: In the Context of Restaurant Brands. European Journal of Marketing, 50(7/8), 1348-1376. https://doi.org/10.1108/EJM-032015-0144

Japutra, A., Ekinci, Y., Simkin, L., \& Nguyen, B. (2018). The Role of Ideal Self-Congruence and Brand Attachment in Consumers' Negative Behaviour: Compulsive Buying and External Trash-Talking. European Journal of Marketing, 52(3/4), 683-701. https://doi.org/10.1108/EJM-06-2016-0318

Kim, H., Ahn, S.-K., \& Forney, J. A. (2014). Shifting Paradigms for Fashion: From Total to Global to Smart Consumer Experience. Fashion and Textiles, 1(1). https://doi.org/10.1186/s40691-014-0015-4

Kolar, T., \& Zabkar, V. (2010). A Consumer-Based Model of Authenticity: An Oxymoron or the Foundation of Cultural Heritage Marketing? Tourism Management, 31(5), 652-664. https://doi.org/10.1016/j.tourman.2009.07.010 
Kotler, P., Kartajaya, H., \& Setiawan, I. (2019). Marketing 3.0: From Products to Customers to the Human Spirit. In K. Kompella (Ed.), Marketing Wisdom (1st ed., pp. 139-156). https://doi.org/10.1007/978-981-10-77241 10

Kotler, P., \& Zaltman, G. (1997). Social Marketing: An Approach to Planned Social Change. Social Marketing Quarterly, 3(3-4), 7-20. https://doi.org/10.1177/152450049700300301

Luna-Cortés, G. (2017). The Influence of Symbolic Consumption on Experience Value and the Use of Virtual Social Networks. Spanish Journal of Marketing - ESIC, 21(1), 39-51. https://doi.org/10.1016/j.sjme.2016.12.005

Majeed, M. H. (2019). Pragmatist Inquiry in to Consumer Behaviour Research. Philosophy of Management, 18(2), 189-201. https://doi.org/10.1007/s40926-018-0103-4

Moulard, J. G., Garrity, C. P., \& Rice, D. H. (2015). What Makes a Human Brand Authentic? Identifying the Antecedents of Celebrity Authenticity. Psychology and Marketing, 32(2), 173-186. https://doi.org/10.1002/mar.20771

Quinton, S. (2013). The Community Brand Paradigm: A Response to Brand Management's Dilemma in the Digital Era. Journal of Marketing Management, 29(7-8), 912-932. https://doi.org/10.1080/0267257X.2012.729072

Reisinger, Y., \& Steiner, C. J. (2006). Reconceptualizing Object Authenticity. Annals of Tourism Research, 33(1), 65-86. https://doi.org/10.1016/j.annals.2005.04.003

Rose, G. M., \& Orr, L. M. (2007). Measuring and Exploring Symbolic Money Meanings. Psychology and Marketing, 24(9), 743-761. https://doi.org/10.1002/mar.20182

White, K., Habib, R., \& Hardisty, D. J. (2019). How to SHIFT Consumer Behaviors to be More Sustainable: A Literature Review and Guiding Framework. Journal of Marketing, 83(3), 22-49. https://doi.org/10.1177/0022242919825649 